\title{
Impact of bariatric surgery on depression and anxiety symptons, bulimic behaviors and quality of life
}

\section{O impacto da cirurgia bariátrica nos sintomas depressivos e ansiosos, comportamento bulímico e na qualidade de vida}

Bárbara Tae ${ }^{1}$; Elisabeth Rosa Pelaggl ${ }^{1}$; Julia Guglielmi Moreira ${ }^{1}$; Jaques Waisberg, TCBC-SP2; Leandro Luongo de Matos, MD Phd ${ }^{3}$; GILBERTO D'Elia, MD PhD ${ }^{4}$

\section{A}

\begin{abstract}
Objective: To assess psychiatric symptoms, substance use, quality of life and eating behavior of patients undergoing bariatric surgery before and after the procedure. Methods: We conducted a prospective longitudinal study of 32 women undergoing bariatric surgery. To obtain data, the patients answered specific, self-administered questionnaires. Results: We observed a reduction in depressive and anxious symptoms and also in bulimic behavior, as well as an improved quality of life in the physical, psychological and environmental domains. There was also a decrease in use of antidepressants and appetite suppressants, but the surgery was not a cessation factor in smoking and / or alcoholism. Conclusion: a decrease in psychiatric symptoms was observed after bariatric surgery, as well as the reduction in the use of psychoactive substances. In addition, there was an improvement in quality of life after surgical treatment of obesity.
\end{abstract}

Key words: Bariatric surgery. Morbid obesity. Depression. Quality of life.

\section{INTRODUCTION}

$\mathrm{O}^{\mathrm{b}}$ besity is a disease of epidemic proportions, representing a major public health problem ${ }^{1-6}$. According to the World Health Organization, there are at least 300 million obese people in world ${ }^{7}$. Its prevalence has increased alarmingly, leading more and more people to seek bariatric surgery (BS) as a treatment option due to the difficulty in obtaining good results in clinical treatments for weight reduction $1,2,5,8,9$.

Obesity is objectively classified by the body mass index (BMI), calculated as the ratio between the weight and the square height of the individual, and obesity is defined when the patient has a BMI > 40kg/ $\mathrm{m}^{2}$. Currently, BS is indicated for patients with BMI $>40 \mathrm{Kg} / \mathrm{m}^{2}$ or above $35 \mathrm{Kg} / \mathrm{m}^{2}$ associated with lifethreatening comorbidities ${ }^{10}$. Many patients show improvement or even cure of the comorbidities associated with obesity after surgery ${ }^{5,11}$. Typically, BS promotes quality of life benefit, mitigating the psychiatric symptoms, improving social sphere, self-esteem and even the financial condition of the patient 5,9,12-19.

There is no consensus on the criteria for psychiatric assessment of applicants for BS. There are no precise data adequately studied and / or proven on the influence of BS on the psychological behavior of patients ${ }^{12,16,20}$. Thus, as the number of patients undergoing BS increases, so does the need to understand how psychiatric symptoms may influence the results of the operation $8,9,17$.

The aim of this study was to evaluate the psychiatric symptoms (depressive and anxious), substance use, quality of life and eating behavior of patients seeking bariatric surgery as a treatment for morbid obesity, and to compare the results of the evaluation conducted pre- and postoperatively.

\section{METHODS}

The research protocol was approved by the Ethics in Research Committee of the ABC Faculty of Medicine, under No 088/2009. Patients included in the study were informed about the research objectives, as well as the voluntary nature of their participation, and signed the Instrument of due consent.

We conducted a prospective, longitudinal study of 32 women who underwent BS in the period between January 2008 and November 2011 at the Department of General Surgery, ABC Faculty of Medicine.

Inclusion criteria were adult patients with BMI e" $40 \mathrm{~kg} / \mathrm{m}^{2}$ or BMI e" $35 \mathrm{~kg} / \mathrm{m}^{2}$ associated with comorbidities; stable obese for at least five years; absence

1. Medical School Graduate; 2. Disciplines of General Surgery; 3. Collective Health; 4. Psychiatry, Facudade de Medicina do ABC, Santo André, São Paulo - SP, Brazil. 
of illicit drugs or alcohol abuse (for alcoholism we used the criteria for substance abuse and dependence of DSM-IV) 21; absence of moderate or severe psychosis or dementia; understanding by the patient and their families of the risks and changes inherent to major surgery and the need for postoperative follow-up with a multidisciplinary team throughout the patient's life. These criteria are in accordance with the resolution in 1942/2010 of the Brazilian Federal Council of Medicine. Only female patients were selected due to the higher frequency of psychiatric symptoms observed in this population and aiming at sample homogenization 2,8,22-24. Illiterate patients and/or the presence of prior severe psychiatric disorder were exclusion criteria.

The evaluations were performed in two stages. The first one three months to one month before the procedure, and the second, between six and ten months after the operation. To obtain the data, the patients responded to five self-administered questionnaires that were completed without an interview and without the assistance of researchers, through reading and selfreporting.

The following questionnaires were employed: 1) Beck Depression Inventory (BDI): a self-report instrument, validated in Portuguese, which focuses on symptoms and attitudes such as: sadness, sense of failure, lack of satisfaction, feeling of guilt, feelings of punishment, self-deprecation, auto-accusations, suicidal ideas, crying spells, fatigue, loss of appetite, weight loss, somatic concerns, and decreased libido. Although void of diagnostic purposes, it allows to reliably classify depressive symptoms, measuring not only the "general psychopathology" (here the term used by the authors with no sense of semiotics science), but also specific aspects of depression. It consists of 21 items, including symptoms and attitudes, whose intensity varies from 0 to 3 according to severity of symptoms, with the following groups according to the cutoff points: (1) 0-9 = no or minimal depression; (2) 10-18= mild to moderate depression; (3) 19-29 = moderate to severe depression; (4) 30-63 = severe depression ${ }^{25}$; 2) State-Trait Anxiety Inventory (STAI): a questionnaire consisting of two distinct scales designed to measure two concepts of anxiety, i.e., anxious state (STAI State) and anxious trait (STAl Trait). Each scale consists of 20 statements in which the volunteers indicate the intensity at the moment (STAI State) or the frequency with which they occur (STAI Trait) by means of a four-point scale (14), with the following groups according to the cutoff points: (1) $<33=$ no anxiety or low anxiety; (2) 33-49 = average anxiety; (3) > $49=$ high anxiety ${ }^{26}$; 3) Bulimic Investigatory Test, Edinburgh (BITE): a survey of 30 question that identifies individuals with behaviors and symptoms of bulimia nervosa, with responses of yes or no ${ }^{27}$. In this study we used only the Symptomatic scale that assesses the degree of present food symptoms. It returns the following groups according to the scores: (1) $d " 9=$ minimum or absent bulimic behavior; (2) 10-19= unusual eating pattern (moderate bulimic behavior); (3) e" 20 compulsive eating behavior with a high possibility of bulimia nervosa (severe) ${ }^{28}$; 4) Quality of Life Scale (WHOQOL): used to assess quality of life in adult populations, contains 26 questions, 24 of which are divided into four domains: physical, psychological, social relationships and environment. The domains are represented by various facets and their questions were formulated for Likert-type scale responses, with intensity scale (nothing-extremely), capacity (nothing-completely), frequency (never-always) and evaluation (very dissatisfied-very satisfied; very badvery good). Besides the four domains, the instrument features two general questions: one refers to the perception of quality of life, and the other to satisfaction with health ${ }^{29}$; 5) Inventory on substance use: the profiling of the patients regarding the use of psychoactive substances was performed by structured interview, based on the evaluation criteria of the DSM-IV for the use of different substances ${ }^{21}$.

Values obtained of each continuous variable are presented as mean and standard deviation and categorized by absolute and relative frequencies. Distributions were defined as non-parametric by the Kolmogorov-Smirnov test. Comparisons of the frequency of a phenomenon among groups of qualitative variables were performed by applying the chi-square and McNemar tests for binary dependent variables. Comparisons between continuous dependent variables were carried out with the Wilcoxon test.

\section{RESULTS}

The group was initially composed of 32 women undergoing surgical treatment for obesity. The mean age was $41 \pm 11.6$ years, most were married, without comorbidities, white, Catholic, with completed high school. We observed a significant reduction in body weight and also in body mass index after the surgery (Table 1).

The application of the questionnaire in the postoperative period was possible in only 23 patients (71.9\%); two (6.2\%) were lost to postoperative follow-up, two $(6.2 \%)$ were not found to new interview, four $(12.5 \%)$ declined to respond to questionnaires after the operation, and one (3.1\%) gave up surgical treatment. There was a reduction in depressive symptoms classified as severe or moderate, from $78.2 \%$ preoperatively to $43.5 \%$ after surgery $(p=0.043)$. Similarly, we found a reduction in moderate or severe anxiety symptoms from $87.0 \%$ preoperatively to $56.5 \%$ postoperatively $(p=0.014)$. We also identified a reduction in bulimic behavior from $78.3 \%$ before surgery to $21.7 \%$ postoperatively $(p=0.022)$; there was no case of severe bulimic behavior after surgery. We observed a significant increase in quality of life in the physical, psychological and environmental domains 
Table 1 - Epidemiological data from patients enrolled in the study $(\mathrm{n}=32)$.

\begin{tabular}{|c|c|c|}
\hline Variable* & & sult \\
\hline Age (years) & & \pm 11.6 \\
\hline Weight before the operation $(\mathrm{kg})$ & 117.2 & \pm 18.1 \\
\hline Weight after the operation $(\mathrm{kg} ; \mathrm{n}=23)$ & 87.1 & \pm 18.9 \\
\hline BMI before the operation $\left(\mathrm{kg} / \mathrm{m}^{2}\right)$ & 45.7 & \pm 6.7 \\
\hline BMI after the operation $\left(\mathrm{kg} / \mathrm{m}^{2} ; \mathrm{n}=23\right)$ & 33.6 & \pm 7.0 \\
\hline Marital status & 16 & $(50.0 \%)$ \\
\hline Married/stable & 6 & $(18.7 \%)$ \\
\hline Single & 3 & $(9.4 \%)$ \\
\hline Divorced & & \\
\hline Widow & 7 & $(21.9 \%)$ \\
\hline Current spouse & & \\
\hline Yes & 22 & $(68.7 \%)$ \\
\hline No & 10 & $(31.3 \%)$ \\
\hline Comorbidities (HT and/or DM) & & \\
\hline Yes & 15 & $(46.8 \%)$ \\
\hline No & 17 & $(53.2 \%)$ \\
\hline Color & & \\
\hline White & 22 & $(68.7 \%)$ \\
\hline Brown & 8 & $(25.0 \%)$ \\
\hline Black & 2 & $(6.3 \%)$ \\
\hline Profession & & \\
\hline Casual employment & 1 & $(3.2 \%)$ \\
\hline Formal employment & 13 & $(40.6 \%)$ \\
\hline Housewife & 18 & $(56.2 \%)$ \\
\hline Level of education (education) & & \\
\hline Incomplete junior school & 2 & $(6.3 \%)$ \\
\hline Complete junior school & 6 & $(18.7 \%)$ \\
\hline Incomplete high-school & 8 & $(25 \%)$ \\
\hline Complete high-school & 16 & $(50 \%)$ \\
\hline Religion & & \\
\hline Catholic & 16 & (50\%) \\
\hline Evangelical & 11 & $(34.4 \%)$ \\
\hline Spiritualist & 2 & $(6.2 \%)$ \\
\hline Agnostic & 1 & $(3.2 \%)$ \\
\hline Not informed & 2 & $(6.2 \%)$ \\
\hline
\end{tabular}

BMI (body mass index), HT (hypertension) and DM (diabetes mellitus)

$(p<0.0001, p=0.001$ and $p=0.009$, respectively), but not for the social one $(p=0.081)$ (Table 2$)$.

Studying the use of psychoactive substances in the lives of these patients before surgery and comparing them with their use within six months after the procedure, we observed a decreased use of antidepressants and appetite suppressants. However, the operation was not a determining factor for the decreased use of tobacco or alcohol (Table 3).

There was no significant difference between the preoperative use of substances and scores presented in the scales of psychiatric symptoms; between preoperative BMI and the domains of quality of life (WHOQOL). Likewise, there was no difference between BMI and substance use prior to surgery.

\section{DISCUSSION}

Currently, obesity is the most common preventable chronic disease in society, as its prevalence has increased alarmingly. However, we note that about $20 \%$ of patients fail to lose significant amount of weight after the operation and this event is often attributed to psychological factors and not necessarily to operative technical factors $5,12,18,30$. Thus, it is important to study the changes of behavior that this procedure can generate on patients $1-3,6,8,17,18$.

Approximately $15-30 \%$ of patients who apply to BS exhibit clinically significant symptoms of depression, and most bariatric surgery centers consider their presence a contraindication for the operation ${ }^{3,4,13,18,20}$. It has been shown that these patients have higher risk of developing symptoms of anxiety and depression than the general population and that BS can lead to significant reduction of such symptoms $2,3,8,13,14,16$. In the present study we observed that patients seeking the operation had characteristics of severe depression. Moreover, after the procedure, these patients showed improvement in depression score, which goes against the findings of the literature on this parameter $2,13,18,30$

We also noted that patients had symptoms of anxiety in moderate levels before operation and decreased to lower scores postoperatively. Wadden et al. ${ }^{13}$ reported that morbidly obese patients are at increased risk for developing symptoms of anxiety, depression and bulimia in relation to the general population and that bariatric surgery can lead to significant reduction of such symptoms, which was also observed in this study.

Changes in feeding behavior should also be studied for this group of patients, since it can bring postoperative complications and jeopardize surgical outcome 2,12,31. Approximately $30-50 \%$ of morbidly obese patients have altered feeding behavior $4,12,31$. In the concept of "addiction transfer", food is replaced by another substance as an alternative strategy, which could lead to increased use of psychoactive substances, particularly alcohol, in the postoperative period ${ }^{5}$. This event, however, was not identified in the study, since there was no significant difference between the use of alcohol and tobacco before and after the operation, and the use of antidepressants and appetite suppressants decreased after surgery. We found that the use of alcohol and tobacco in the sample of the present study is lower than that of the population at large; the use of antidepressant and anorectics, on its turn, was much higher than that of the Brazilian population ${ }^{31,32}$.

There is limited information about the predictors of psychiatric symptoms in patients who will undergo surgical treatment of obesity and BMI was considered a poor 
Table 2 - Pre- and postoperative Comparison of questionnaires Beck, STAI, BITE and WHOQOL $(n=23)$.

\begin{tabular}{|c|c|c|c|c|c|}
\hline Variable* & Preo & erative & Postoperati & ive Period & $p * *$ \\
\hline \multicolumn{6}{|l|}{ Beck Score } \\
\hline 1- Minimal or none & 2 & $(8.8 \%)$ & 5 & $(21.7 \%)$ & 0.043 \\
\hline 2- Slight & 3 & $(13.0 \%)$ & 8 & $(34.8 \%)$ & \\
\hline 3- Moderate & 7 & $(30.4 \%)$ & 8 & $(34.8 \%)$ & \\
\hline 4- Severe & 11 & $(47.8 \%)$ & 2 & $(8.7 \%)$ & \\
\hline \multicolumn{6}{|l|}{ STAI Score } \\
\hline 1- Low & 3 & $(13.0 \%)$ & 10 & $(43.5 \%)$ & 0.014 \\
\hline 2- Moderate & 11 & $(47.9 \%)$ & 11 & $(47.8 \%)$ & \\
\hline 3- High & 9 & $(39.1 \%)$ & 2 & $(8.7 \%)$ & \\
\hline \multicolumn{6}{|l|}{ BITE Score } \\
\hline 1- Minimal or none & 5 & $(21.8 \%)$ & 18 & $(78.3 \%)$ & 0.022 \\
\hline 2- Moderate & 15 & $(65.2 \%)$ & 5 & $(21.7 \%)$ & \\
\hline 3- Severe & 3 & $(13.0 \%)$ & - & & \\
\hline \multicolumn{6}{|l|}{ WHOQOL (domains) } \\
\hline - Physical & $40.54 \pm$ & 18.97 & $70.49 \pm$ & 22.28 & $<0.0001$ \\
\hline - Psychological & $48.18 \pm$ & 18.87 & $70.28 \pm$ & 17.91 & 0.001 \\
\hline - Social & $56.15 \pm$ & 23.33 & $68.11 \pm$ & 27.93 & 0.081 \\
\hline - Environmental & $48.23 \pm$ & 12.91 & $58.28 \pm$ & 13.67 & 0.009 \\
\hline
\end{tabular}

* Qualitative variables expressed in percentage (\%), absolute frequency ( $n$ ) and quantitative variables expressed as mean \pm standard deviation ** Chi-square test for questionnaires of Beck, STAI and BITE, and Wilcoxon test for analysis of the domains of the WHOQOL

Table 3 - Substance use preoperatively and postoperatively $(n=23)$.

\begin{tabular}{lccr}
\hline Substance * & Preoperative & Postoperative & $\mathbf{p}^{*}$ * \\
\hline Tabacco & $9(39.1 \%)$ & $4(17.4 \%)$ & 0.180 \\
Alcohol & $12(52.2 \%)$ & $6(26.1 \%)$ & 0.109 \\
Appetite suppressants & $20(87.0 \%)$ & $0(0.0 \%)$ & NA \\
Antidepressants & $12(52.2 \%)$ & $3(13.0 \%)$ & 0.022 \\
\hline
\end{tabular}

* Variables expressed in absolute frequency and percentage.

* * McNemar's test.

NA: not applicable (the non-use of appetite suppressants postoperatively was a constant).

predictor for the presence of anxiety and depressive symptoms in these patients $2,5,12,13,16,30$. We found no correlation between $\mathrm{BMI}$ and psychiatric symptoms, which is consistent with the literature 16. Likewise, there was no relationship between $\mathrm{BMI}$ and impairment of quality of life in any of the domains, unlike what was found by Wadden et al. ${ }^{13}$.

Morbidly obese patients seem to have an impaired quality of life, and for most of these patients, BS improved the physical domain and other aspects of quality of life $9,12,13,17,19,31,33$. In the present study we observed improvement of physical, psychological and environmental parameters of quality of life after surgical treatment. However, there was no change in the social domain, confirming that the changes, physical or mental, caused by the operation do not interfere in the social activities of these individuals ${ }^{9}$.
The results of this study should be seen cautiously, as they represent the reality of one service and a small sample. However, the study sought to include an overview of the psychological and behavioral implications of these patients through the application of five specific questionnaires.

Therefore, we conclude that there was decrease in psychiatric symptoms (depressive, anxious and bulimic), reduced substance use and improved quality of life of patients after surgical treatment of obesity.

\section{Acknowledgements}

To Prof. Dr. Luiz Gonzaga Cavalcante, developer of this research, for sharing his knowledge in the field of bariatric surgery, by enabling contact with patients during their consultations at the Mario Covas State Hospital in Santo André, and for his patience and dedication. 


\title{
R E S U M O
}

\begin{abstract}
Objetivo: avaliar a sintomatologia psiquiátrica, o uso de substâncias, a qualidade de vida e o comportamento alimentar de pacientes submetidos a cirurgia bariátrica antes e após o procedimento. Métodos: estudo longitudinal prospectivo com 32 mulheres submetidas à cirurgia báriatrica. Para a obtenção de dados, as pacientes responderam a questionários específicos, autoaplicados. Resultados: foi identificada uma redução na sintomatologia depressiva e ansiosa e também no comportamento bulímico, bem como uma melhora na qualidade de vida nos domínios físico, psíquico e ambiental. Houve diminuição do uso de antidepressivos e de moderadores de apetite, porém a cirurgia não foi um fator determinante na cessação do tabagismo elou etilismo. Conclusão: foi observada uma diminuição da sintomatologia psiquiátrica após a cirurgia bariátrica bem como redução do uso de substâncias psicoativas. Além disso, houve melhora na qualidade de vida após o tratamento cirúrgico da obesidade.
\end{abstract}

Descritores: Cirurgia bariátrica. Obesidade mórbida. Depressão. Qualidade de vida.

\section{REFERENCES}

1. Anderi E Jr, Araújo LGC, Fuhro FE, Godinho CA, Henriques AC. Experiência inicial do serviço de cirurgia bariátrica da Faculdade de Medicina do ABC. Arq Med ABC. 2007;32(1):25-9.

2. Petribu K, Ribeiro ES, Oliveira MFM, Braz CIA, Gomes MLM, Araujo DE, et al. Transtorno da compulsão alimentar periódica em uma população de obesos mórbidos candidatos à cirurgia bariátrica do Hospital Universitário Oswaldo Cruz, em Recife - PE. Arq Bras Endocrinol Metabol. 2006;50(5):901-8.

3. Hayden MJ, Dixon JB, Dixon ME, O'Brien PE. Confirmatory factor analysis of the Beck Depression Inventory in obese individuals seeking surgery. Obes Surg. 2010;20(4):432-9.

4. Holt Rl. Obesity - an epidemic of the twenty-ûrst century: an update for psychiatrists. J Psychopharmacol. 2005;19(6 Suppl):615.

5. Odom J, Zalesin KC, Washington TL, Miller WW, Hakmeh B, Zaremba $\mathrm{DL}$, et al. Behavioral predictors of weight regain after bariatric surgery. Obes Surg. 2010;20(3):349-56.

6. Toussi R, Fujioka K, Coleman KJ. Pre- and postsurgery behavioral compliance, patient health, and postbariatric surgical weight loss. Obesity. 2009;17(5):996-1002

7. World Health Organization [homepage in internet]. Childhood overweight and obesity. Acesso em: 15 fev 2012. Disponível em: http://www.who.int/dietphysicalactivity/childhood/en/

8. Munoz DJ, Chen E, Fischer S, Roehrig M, Sanchez-Johnson L, Alverdy J, et al. Considerations for the use of the Beck Depression Inventory in the assessment of weight-loss surgery seeking patients Obes Surg. 2007;17(8):1097-101.

9. Sociedade Brasileira de Cirurgia Bariátrica e Metabólica [homepage na internet]. Resolução CFM no 1942, de 12 de fevereiro de 2010. Altera a Resolução CFM no 1766, de 13 de maio de 2005, publicada no Diário Oficial da União em 11 de julho de 2005, Seção I, página 114, que estabelece normas seguras para o tratamento cirúrgico da obesidade mórbida, definindo indicações, procedimentos e equipe [acessado em: 15 fev 2012]. Disponível em URL: http://www.sbcb.org.br/download/1942.pdf

10. Khawali C, Ferraz MB, Zanella MT, Ferreira SRG. Evaluation of quality of life in severely obese patients after bariatric surgery carried out in the public healthcare system. Arq Bras Endocrinol Metab. 2012;56(1):33-8.

11. O'Brian PE. Bariatric Surgery: mechanisms, indications and outcomes. J Gastroenterol Hepatol. 2010;25(8):1358-65

12. Herpertz S, Kielmann R, Wolf AM, Hebebrand J, Senf W. Do psychosocial variables predict weight loss or mental health after obesity surgery? A systematic review. Obes Res. 2004;12(10):155469.

13. Wadden TA, Sarwer DB, Fabricatore AN, Jones $L$, Stack R, Williams NS. Psychosocial and behavioral status of patients undergoing bariatric surgery: what to expect before and after surgery. Med Clin North Am. 2007;91(30:451-69, xi-xii.
14. Ali MR, Rasmussen JJ, Monash JB, Fuller WD. Depression is associated with increased severity of co-morbidities in bariatric surgical candidates. Surg Obes Relat Dis. 2009;5(5):559-64

15. Ronchi A, Marinari GM, Sukkar SG, Scopinaro N, Adami GF. Behavioral characteristics of severely obese patients seeking bariatric surgery: cross-sectional study with alimentary interview. Behav Med. 2008:33(4):145-50.

16. Andersen JR, Aasprang $A$, Bergsholm $P$, Sletteskog $N$, Våge $V$, Natvig GK. Anxiety and depression in association with morbid obesity: changes with improved physical health after duodenal switch. Health Qual Life Outcomes. 2010:8:1-7.

17. Dymek MP, Le Grange D, Neven K, Alverdy J. Quality of life after gastric bypass surgery: a cross-sectional study. Obes Res. 2002;10(11):1135-42.

18. de Zwaan M, Enderle J, Wagner S, Mühlhans B, Ditzen B, Gefeller $O$, et al. Anxiety and depression in bariatric surgery patients: a prospective, follow-up study using structured clinical interviews. J Affect Disord. 2011;133(1-2):61-8.

19. Sarwer DB, Wadden TA, Moore RH, Eisenberg MH, Raper SE, Williams NN. Changes in quality of life and body image after gastric bypass surgery. Surg Obes Relat Dis. 2010;6(6):608-14

20. Fabricatore AN, Sarwer DB, Wadden TA, Combs CJ, Krasucki JL. Impression management or real change? Reports of depressive symptoms before and after the preoperative psychological evaluation for bariatric surgery. Obes Surg. 2007;17(9):1213-9.

21. American Psychiatric Association. Diagnostic and statistical manual of mental disorders. DSM-IV [internet]. 4th ed. Washington (DC): American Psychiatric Association; 1994 [acessado em: fevereiro de 2012]. 866 p. Disponível em: http:// www.psychiatryonline.com/DSMPDF/dsm-iv.pdf

22. Andrade LHSG, Viana MC, Silveira CM. Epidemiologia dos transtornos psiquiátricos na mulher. Rev Psiq Clin. 2006;33(2):43-54

23. Pinzon $\vee$, Nogueira FC. Epidemiologia, curso e evolução dos transtornos alimentares. Rev Psiq Clin. 2004;31(4):158-60.

24. Baptista MN, Baptista ASD, Oliveira MG. Depressão e gênero: por que as mulheres deprimem mais que os homens? Temas psicol. 1999; 7(2):143-56.

25. Beck AT, Ward CH, Mendelson M, Mock J, Erbaugh J. An inventory for measuring depression. Arch Gen Psychiatry. 1961;4:561-71.

26. Spielberger CD, Gorsuch RL, Lushene RE. Inventário de ansiedade traço-estado - IDATE. Tradução de Ângela M B Biaggio e Luís Natalício. Rio de Janeiro: CEPA; 1979.

27. Henderson $M$, Freeman CP. A self-rating scale for bulimia. The 'BITE'. Br J Psychiatry. 1987;150:18-24.

28. Cordás TA, Hochgraf PB. O "BITE": instrumento para avaliação da bulimia nervosa - versão para o português. J bras psiquiatr. 1993;42(3):141-4.

29. Fleck MPA, Lousada S, Xavier M, Chachamovich E, Vieira G, Santos $L$, et al. Aplicação da versão em português do instrumento de avaliação de qualidade de vida da Organização Mundial da Saúde (WHOQOL-100). Rev Saúde Publíca. 1999:33(2):198-205. 
30. Abilés V, Rodríguez-Ruiz S, Abilés J, Mellado C, García A, Pérez de la Cruz A, et al. Psychological characteristics of morbidly obese candidates for bariatric surgery. Obes Surg. 2010;20(2):161-7.

31. Rutledge T, Adler S, Friedman R. A prospective assessment of psychosocial factors among bariatric versus non-bariatric surgery candidates. Obes Surg. 2011;21(10):1570-9.

32. II Levantamento domiciliar sobre o uso de drogas psicotrópicas no Brasil: estudo envolvendo as 108 maiores cidades do país. São Paulo: CEBRID; 2005

33. Josbeno DA, Jakicic JM, Hergenroeder A, Eid GM. Physical activity and physical function changes in obese individuals after gastric bypass surgery. Surg Obes Relat Dis. 2010;6(4):361-6
Received on 11/01/2013

Accepted for publication 30/03/2013

Conflict of interest: none.

Source of funding: none.

Address for correspondence:

Leandro Luongo de Matos

E-mail: Imatos@amcham.com.br 